\title{
IMPROVING STUDENTS' LEARNING MOTIVATION IN READING COMPREHENSION USING RECIPROCAL TEACHING
}

\author{
Helmi Gunawan ${ }^{(1)}$ Ratna ${ }^{(2)}$ \\ STT Ronggolawe Cepu
}

DOI : 10.23917/varidika.v31vi2i.10217

\begin{abstract}
Submission
Track:

Received:

29 July 2019

Final Revision:

29 October 2019

Available online:

27 December 2019

Corresponding

Author:

Name \& E-mail Address

ABSTRACT

Teaching reading comprehension to the students is not easy. The teacher often finds a lot of students' learning motivation problems from the students. The students' problems are (1) students' interest, (2) students' effort, (3) self responsibility activity or persistence, (4) students' optimal experiences; (5) reinforcement and teacher's method. One of the efforts to minimize the problems is by empowering the students in the learning process. One of the teaching techniques that can empower learners is Reciprocal Teaching Method.

An action research was carried out and aimed at finding out whether Reciprocal teaching can improve the students' learning motivation in reading comprehension in classroom when the teacher applies reciprocal teaching. Two cycles are applied. The data are taken by observing the learning process when an action is applied, by interviewing the learners Helmi Gunawan ${ }^{(1)}$ STT Ronggolawe Cepu helmig8512@gmail.com involved, by giving questionnaires and by conducting interview. The finding of the research shows that Reciprocal Teaching Method can improve the students' learning motivation in reading comprehension when it is applied.

Keywords: Reciprocal Teaching Method, Motivation, Reading)
\end{abstract}

\section{INTRODUCTION}

English is taught in every level of education and various of departements. It is also taught in Mechanical Engineering Departement of STTR Cepu. Experienced teachers know very well the problems faced by the students in learning English as a Foreign Language. Learning motivation is the problem faced by the students, especially for Mechanical Engineering Students of STTR Cepu. The researcher also conducted a pre questionnaire to the students related to their problems. After analyzing the result, the researcher found two kinds 
of students' learning motivation problems. They were intrinsic factor and extrinsic factor. There were four causes of their intrinsic motivation: (1) Students' interest was low, (2) Students' effort was lack, (3) Students' self responsibility /persistence was low, and (4) Students' optimal experience was low. Moreover, the fact that there was also extrinsic factor: (1) no any variety of method ever implemented by the teacher in teaching reading, and (2) the teacher seldom gave the reinforcement to the students (Striklin, 2011).

Therefore, based on the problem above, the writer attempts to find a technique, method or strategy that can be applied in classroom that can hopefully improve their learning motivation. In order to solve and to improve the students' learning motivation, Reciprocal Teaching Method seems to be the effective way that the teacher could implement in the classroom. Reciprocal Teaching Method seems to be the effective way that the teacher could implement in the classroom. Reciprocal Teaching is a cooperative learning method of improving reading comprehension that can also be used in individual tutoring/teaching. In reciprocal teaching a teacher/tutor and a group of students take turns leading discussions about specific segments of text using reading strategies of questioning, clarifying, summarizing and predicting (Palincsar, 1986).

The researcher used the Reciprocal Teaching Strategy to solve the problem with Reciprocal has many advantages. According to (Palincsar, 1986), Reciprocal Teaching strategy has some advantages. As in the following :

1) greater knowledge of the topic;

2) improved reading skills of the students;

3) more positive attitudes when extracting, organising, and recording information from the text;

4) more self confidence and motivation of students to read the text;

5) improved leadership skills of students;

6) increased co-operation and greater initiative of students.

This method can motivate the students in learning reading comprehension. According to (Striklin, 2011:624) states that the core design behind Reciprocal Teaching Method is to motivate students to encourage and help each other master reading skill presented by the teacher. The member of the group must be active to solve the problems because they take turns to indicate the role of teacher and students in dialogue. (Striklin, 2011:620) states that the members of the group are encouraged to predict about where the text is going next by the student teacher. This lets students use their prior knowledge learned in the earlier stages. It means that Reciprocal Teaching Method gives opportunities the students to share their optimal experience through discussion group activity. It also facilitates a group to communicate each other. They may communicate to solve the problems on the content they are reading. The members should be able to ask a relevant question and summary sentence. Reciprocal Teaching Method spends sufficient time using this strategy to reinforce skills. This method allows the students to play role as the teacher, so the student has opportunity to lead. It encourages the students to improve their confident and believe that they are doing something because of their curiosity. In Reciprocal Teaching, they play a role as a teacher, they sit together, face to face one another and share freely based on the problem. In this study, the researcher tried to apply Reciprocal Teaching during the reading activity. Hopefully, it could make the students motivated to exchange knowledge and information each other during reading activity. 


\section{RESEARCH METHOD}

This study is a Classroom Action Research using Reciprocal Teaching Method to improve the students' reading comprehension of Mechanical Engineering Students 1st Semester of STTR Cepu. Furthermore, (McNif, 1992:2) defines that,

"The action research is a form of self-reflective inquire form undertaken by participants (teacher, students, or principals, for example) in some certain social (include education) for increasing the justice and rationality from (a) the social practice activity or their education (b) their understanding about the practical activities on education practice, (c) This situation probably do the practical activity. Shortly, the action research is how the group of teachers can organize the learning practice, and learn from their experiment itself".

This method is taken as it is more oriented to the process than to the result. To enhance the quality of the process, the teacher needs to pay a great attention on the learning process. Consequently, learning will be effective.

The research takes place in STTR Cepu. The subjects of the research are the students of Mechanical Engineering Students 1st Semester of STTR Cepu. There are four instruments employed to collect the data, namely: interview to the informant (appointed the students); observation to the event or field note; questionnaire to find out the development of students' learning motivation; and the tests to find out the development of students' reading comprehension.

\section{RESULTS \& DISCUSSION}

\section{Findings}

\section{Pre-Research}

There were four main activities in pre-research, namely observing the teaching learning process, giving questionnaire, interviewing the students, giving pre-test, and preparing the materials, and lesson plans.

The research was done at Mechanical Engineering Students 1st Semester of STTR Cepu. The amount of the students is 29 students who come from different city.

Based on the class pre test results, the researcher concluded that $62 \%$ of the students had difficulty in identifying main idea of texts, 59\% students could not find explicit, $51 \%$ students could not find implicit information easily, $69 \%$ of them had found with word reference tasks easily, and $56 \%$ students needed extra time and high concentration to accomplish tasks dealing with finding the meaning of certain words.

The researcher teaches Mechanical Engineering Students 1st Semester of STTR Cepu. The observation was done in these three classes. The result of the observation showed that the students of Mechanical Engineering Students 1st Semester of STTR Cepu were passive during the reading class, they preferred chat with their friends to completed their tasks, they were not interested in reading long texts, they were reluctant to study English, especially reading. The data were supported by the result of the students' questionnaire and interview.

This research was conducted in two cycles. Every cycle covers planning, action, observation and reflection.

\section{Cycle 1}


In Cycle 1, the researcher implemented the plans he had made before. In this part, the researcher did a set of activities which consisted of planning the action, implementing the action, observing the action, and reflecting the observation result which included 3 meetings and one post-test after all meetings completed. The materials in this cycle focused on hortatory exposition text only. The researcher also provided the field note and questioner after the method was implemented.

\section{Students' Reading Comprehension}

After reciprocal teaching was implemented, the students' reading comprehension showed improvement. Based on the result of post-test and observation, the students made good progress in comprehending reading text. The improvement can be recognized by comparing the students' average score of post-tests of cycle 1. The students' average score of pre-tests is 61 and the students' average score of post-tests of cycle 1 is 72 . So, there is an improvement the students' average score in reading from 61 to 72 . Besides, the mean of each indicator also increased. The improvement of each indicator can be shown from the table below:

Table 1. The Mean of Post-test in cycle 1

\begin{tabular}{lll}
\hline \multicolumn{1}{c}{ Indicator } & Mean of Pre-test & $\begin{array}{c}\text { Mean of Post-test } \\
\text { Cycle 1 }\end{array}$ \\
\hline 1. Identifying the main idea of texts & 62 & 65 \\
\hline 2. Finding explicit information & 59 & 61 \\
\hline 3. Identifying implicit information & 51 & 66 \\
\hline 4. Identifying the word reference & 69 & 83 \\
\hline 5. Finding the meaning of certain words & 56 & 57 \\
\hline
\end{tabular}

Besides, the students gave positive respond to this activity. It can be seen from the interview to some students. As one of the students said:

"saya merasa kurang dan belum tahu banyak dalam membaca, jadi saya masih berusaha ingin belajar terus apalagi kosakatanya. Dengan metode ini saya lebih banyak tanya kosakata yang belum saya tau."

Another student said:

"Karena saya dibantu teman kelompok, saya jadi sedikit paham tentang bagaimana cara mencari main idea, metode yang diterapkan membuat saya lebih giat untuk diskusi dengan teman."

\section{Students' Learning Motivation}

Based on the teacher's field notes, questionnaire, and interview, there were some points found in the actions. First, in the first meeting, the students' interest to study English, especially reading, was still low. They were difficult to apply this method. But when in the second meeting, the students' interest increased. It was because they had familiar with the method. They enjoyed in learning and discussing. However, there were 12 students talked with their friend about other material which was not included in the topic. In the third meeting, the number of students who didn't pay attention to the discussion decreased. They enjoyed in discussion group. When they were getting difficulties, they asked to the teacher how to solve their finding.

In the second and third meeting when they were asked to read the text and to do the exercise of hortatory exposition text, they did it enthusiastically. The students' effort increase, it can be seen from trying to understand the text by using reciprocal teaching method. Second, the students' participation towards the lectures were rising, it indicated that their interest was also increasing. All of them were involved actively in the teaching learning process. They 
accomplished every tasks and activities eagerly. Third, they had difficulty to manage their time, especially when they had to discuss using reciprocal teaching method. Most of them could not finish the tasks on time. Fourth, the method which was designed by the teacher was more suitable for the students. Fifth, they could manage their concentration on the lesson only. It indicated that the students' optimal experiences were increasing. Based on the result of the students' questionnaire, the improvement of the students' learning motivation can be shown from the table below:

Table 2. The result of the students' questionnaire

\begin{tabular}{lcccccccc}
\hline \multicolumn{1}{c}{ Indicator } & \multicolumn{3}{c}{$\begin{array}{c}\text { Mean of Pre- } \\
\text { Questionnaire }\end{array}$} & \multicolumn{5}{c}{$\begin{array}{c}\text { Mean of Questionnaire } \\
\text { Cycle 1 }\end{array}$} \\
\cline { 2 - 9 } & SS & S & TS & STS & SS & S & TS & STS \\
\hline Students' Interest & 21.7 & 56.7 & 17.7 & 0.55 & 31.6 & 59.4 & 5.5 & 0 \\
\hline Students' Effort & 8.67 & 63.3 & 22.6 & 2 & 21.3 & 64 & 10 & 2 \\
\hline $\begin{array}{l}\text { Self responsibility activity or } \\
\text { persistence }\end{array}$ & 20 & 53.3 & 22.6 & 0.66 & 26.6 & 58 & 11.3 & 0.66 \\
\hline $\begin{array}{l}\text { Students' optimal experiences } \\
\text { Reinforcement and Teacher's }\end{array}$ & 25.7 & 64.8 & 5.71 & 0.47 & 29.5 & 65.7 & 1.4 & 0 \\
\hline \begin{tabular}{l} 
Method \\
\hline
\end{tabular} & 25.7 & 63.3 & 6.6 & 0.95 & 31.4 & 60 & 4.7 & 0.47 \\
\hline
\end{tabular}

The result of the students' questionnaire was also supported by the result of the interview which was done to clarify the students' questionnaire.

As one of the students said:

"Saya sstuju kalau saya senang mengikuti pelajaran Bahasa Inggris dengan metode pembelajaran yang digunakan oleh guru, tapi juga tergantung sama kelompok juga tad."

Another student said:

"Saya setuju kalau materi yang disampaikan oleh ustad sesuai dengan keinginan saya, missal topic reading tentang perjuangan pemuda dalam mempertahankan NKRI"

Problems Unsolved

Some students were able to overcome their problems dealing with the five indicators. Their scores in the post-test 1 were increasing. On the other hand, the mean scores of the five indicators were also improving, but they did not pass the passing grade of English subject for Mechanical Engineering Students 1st Semester of STTR Cepu yet. It was still far from the expectation, achieving the passing grade 75.00. The result of Cycle 1 needed to be improved in the next cycle in order to achieve the passing grade of English subject.

First, there were still passive students. It was because the students confused with the way the Reciprocal Teaching Method work. It was not surprising because it was their first time; first experience studied using this method. They did not know what to ask when they made conversation in applying the Reciprocal Teaching Method. That was why they kept calling the teacher for their helps. Second, the preparation in the group meeting took at least 10 minutes for each meeting. It meant that the time allotment for the lesson declined. In completing exercises, the students could not manage their time effectively. The time allotment for this task was not sufficient. Third, the teacher was difficult to control the group discussion. When the teacher monitored one group, the other groups interrupted to ask the solving of their problem.

\section{Causes and Solution}

To solve the problems that appeared in cycle 1, the researcher arranged better activities in cycle 2 . Based on the result of the evaluation, the researcher then made some improvements in applying Reciprocal Teaching method as follows: 
a) The teacher guides the students in applying the method by giving the charts of the strategies used in reciprocal teaching.

b) The teacher had to manage the time by giving more caution to the students who were late in completing the task.

c) The teacher had to support the students not to shy in participating in the discussion.

\section{Cycle 2}

The finding of weaknesses of Cycle 1 turned to be the essence of the Cycle 2 planning. Cycle 2 consisted of three meetings and one post-test. The time allotment for each meeting was 80 minutes. The genre would be discussed was narrative text. The researcher also provided the field note and questioner after the method was implemented.

\section{Students' Reading Comprehension}

Based on the observation, the students' reading comprehension increased. In the fourth meeting, there were 6 students got difficult in finding the meaning of word. When they were asked to complete the task after discussing, the 6 students were difficult in finding the meaning of word and 2 students were difficulties in identifying implicit information. Based on the fifth meeting, there was the improvement of the students in finding the meaning of word. There was only one student who found the difficult in identifying the meaning the word. In the last meeting, all the students' reading comprehension improved. Besides that, the improvement of students reading comprehension also can be recognized by comparing the students' average score of post-tests of cycle 2. The students' average score of post-tests of cycle 1 is 72 and the students' average score of post-tests of cycle 2 is 79 . So, there is an improvement the students' average score in reading from 72 to 79 . Besides, the mean of each indicator also increased. The improvement of each indicator can be shown from the table below:

Table 3. The Mean of Post-test in cycle 2

\begin{tabular}{lcc}
\hline \multicolumn{1}{c}{ Indicator } & $\begin{array}{c}\text { Mean of Post-test } \\
\text { Cycle 1 }\end{array}$ & $\begin{array}{c}\text { Mean of Post-test } \\
\text { Cycle 2 }\end{array}$ \\
\hline 1. Identifying the main idea of texts & 65 & 79 \\
\hline 2. Finding explicit information & 61 & 82 \\
\hline 3. Identifying implicit information & 66 & 72 \\
\hline 4. Identifying the word reference & 83 & 87 \\
\hline 5. Finding the meaning of certain words & 57 & 78 \\
\hline
\end{tabular}

\section{Students' Learning Motivation}

The observation results of Cycle 2 In the last three meetings, the students' learning motivation increased. In the fourth meeting, the students' learning motivation increased. The students could interest the process of teaching and learning. They could maintain the time wisely. They enjoyed reading using the chart provided by the teacher as a guide to interact with the group in discussion. But there still 4 students talked with themselves not discussing about the text. They said that, they had already done the task.

In fifth meeting, most of the students gave good responses when the teacher asked the quiz in the end of the activity. They stated that the text was easy to learn using reciprocal teaching method. Based on the teacher's field note, when they applied the method there were almost all students were active in learning reading. When they curios to the difficult word, they asked to the teacher immediately. It meant that their effort relating to the material or the learning was better than before applying the method. 
In the last meeting of cycle 2, it was similar with the previous meeting. Most of the students' learning motivation improved. They were active. They enjoyed in learning the material. They were curios to find to do the task and to ask the difficult word to the teacher or their friend. They said that the teacher wanted to improve the method in improving the students' reading comprehension. Except that, they said that the teacher always appreciated to the students and motivated them too. S11 said, "saya setuju kalau ustad menggunakan metode ini, menurut saya ustad, sungguh-sungguh ingin merubah metode yang biasa ustad gunakan ketika mengajar reading dengan metode yang cocok ini." The observation was also supported by the result of the students' questionnaire; the improvement of the students' learning motivation can be shown from the table below:

Table 4. The result of the students' questionnaire

\begin{tabular}{|c|c|c|c|c|c|c|c|c|}
\hline \multirow[t]{2}{*}{ Indicator } & \multicolumn{4}{|c|}{$\begin{array}{c}\text { Mean of Questionnaire Cycle } \\
1\end{array}$} & \multicolumn{4}{|c|}{$\begin{array}{c}\text { Mean of Questionnaire Cycle } \\
2\end{array}$} \\
\hline & $\mathrm{SS}$ & $\mathrm{S}$ & TS & STS & SS & $\mathrm{S}$ & TS & STS \\
\hline Students' Interest & 31.6 & 59.4 & 5.5 & 0 & 58.3 & 38.3 & 0 & 0 \\
\hline Students' Effort & 21.3 & 64 & 10 & 2 & 35.3 & 61.3 & 0 & 0 \\
\hline $\begin{array}{l}\text { Self responsibility activity } \\
\text { or persistence }\end{array}$ & 26.6 & 58 & 11 & 0.6 & 31.3 & 55.3 & 9.3 & 0.66 \\
\hline $\begin{array}{l}\text { Students' optimal } \\
\text { experiences }\end{array}$ & 29.5 & 65.7 & 1.4 & 0 & 40.4 & 56.1 & 0 & 0 \\
\hline $\begin{array}{l}\text { Reinforcement and } \\
\text { Teacher's Method }\end{array}$ & 31.4 & 60 & 4.7 & 0.47 & 47.6 & 49 & 0 & 0 \\
\hline
\end{tabular}

The result of the students' questionnaire was also supported by the result of the interview which was done to clarify the students' questionnaire.

As one of the students said:

"Saya sangat setuju dengan metode ini, saya saling berkomunikasi dengan guru atau dengan teman saya. Karena dengan metode ini otomatis kita harus saling berkomunikasi."

Another student said:

"Saya sangat senang dengan metode ini, menurut saya dengan kegiatan individu saya

kurang ada dukungan tapi dengan berkelompok saya jadi lebih semangat."

Another student said:

"Saya setuju kalau saya sangat puas bila guru menggunakan metode ini karena guru dengan maksimal memberikan contoh dengan mudah dipahami meskipun sulit untuk menerapkannya."

Based on the finding the researcher found in the previous section, it is recommended to English teacher who apply Reciprocal Teaching Method in teaching and learning reading because Reciprocal Teaching Method should manage the time by giving more caution to the students who were late in completing the task.

The data show that there is improvement in the students' reading comprehension. It proves the students' statements that this medium helped them to understand text. The individual scores of poet test 1 and 2 showed that the most of the students had already passed the passing grade of English subject over. 
The result suggest that a reciprocal teaching method can be better promote the students' liking of English reading, and that they willingly commit more time to study, thus reinforcing their intrinsic and extrinsic motivation and increasing their English reading comprehension. the researcher noted that reciprocal teaching method had significantly promoted users' reading comprehension achievement.

\section{Discussion}

The success of learning process always involves some components. According to Gulo (2002: 8) in (Sutri, 2009:152) the components cover teaching objectives, teachers, students, materials, teaching methods, media, and administrative and financial factors. Teachers, as one of the components play important roles to control, organize, lead, and facilitate the learning process so as to achieve the learning objectives. In relation to their task as facilitator, teachers are required to give chance to the learners to be autonomous to develop their knowledge and skills. The teachers do not dominate the opportunities to transfer their knowledge.

One of teaching techniques that gives much chance for the learners to be active is Reciprocal Teaching Method. After implementing the method, the data show that there is improvement in the students' reading comprehension. It proves the students' statements that this medium helped them to understand text. The individual scores of post-tests 1 and 2 showed that the most of the students had already passed the passing grade of English subject over.

Based on (Yang et al., 2011: 2) stated that according to Palincsar and Brown's study in 1984, RT could lead to a significant improvement in reading comprehension by engaging students in the four strategies of predicting, questioning, clarifying, and summarizing (Fung, Wilkinson, \& Moore, 2003; Palincsar \& Brown, 1984).

The students' problems related to main idea can be solved by the use of text which is provided with illustration or picture. By seeing and predicting the picture, it will be easy for them to guess the point of it. It is done because the books (the government's text book and the student's work sheet (LKS)) used to teach English in MA PPMI Assalaam only consisted of the text itself without any picture or illustration in it to help the students predict the content easily. They rely on the title of the text to predict its content.

The students' lack of vocabulary becomes the main problem of reading. It is impossible to understand the message of a text without having good understanding of words in it. The Reciprocal Teaching Method used in this study is equipped by sharing with their friend or clarifying to the teacher or text-box which is added in the text. According to jurnal of (Ahmadi, 2013) entitiled "Goal of Reciprocal Teaching Strategy Instruction" showed that communicative competence is the purpose of reciprocal teaching strategy instruction teaching and learning (Foster \& Rotoloni, 2005). It stresses the need for meaningful communicative tasks in the language classroom, including those which focus on reciprocal teaching strategy in reading comprehension. Reciprocal teaching strategy practices are related to daily use of English language learning including reading comprehension, for instance, small groups working. Hopefully, this way can help the students to minimize their problems related to finding meaning of certain word.

The problem dealing with word reference can be answered by using questioning to their friend in the group. It will help the students to identify the reference of certain word. The main key in finding explicit and implicit information is having good understanding of a text. Good understanding of text can be trained by reading and summarizing the same kinds of text and completing its comprehension questions as many as possible. In this study, the Reciprocal 
Teaching Method is provided with a number of hortatory exposition and narrative texts and its comprehension questions. They can train themselves to gain information by summarizing with their friend. Their reading abilities will improve if they do it regularly.

The fact is in line with Reciprocal Teaching method as stated by (Sutri, 2009:6) in her journal that there is an improvement of students' interest and understanding in reading text. Moreover, the motivation of the students in learning also improved when they use reciprocal teaching. Therefore, there is an increase in the students' achievement of reading skills when it is Reciprocal Teaching Method. Reciprocal Teaching Method reading strategy impacted young readers' ability to comprehend science text as affirmed by Jennifer and Helena (2001: 1). Based on their research, the effectiveness of Reciprocal Teaching, a reading comprehension instructional technique, has been repeatedly demonstrated.

(Aini, 2011) in her research found that the reciprocal teaching method could improve the students' reading comprehension and the key aspect of reciprocal teaching which were found interesting reading topic, teachers monitoring and students' interaction. The results suggest that a Reciprocal Teaching Method can be better promote the students' liking of English reading, and that they willingly commit more time to study, thus reinforcing their extrinsic motivation and motivational intensity, and increasing their English reading comprehension.

In line with the results of four experts researches on Reciprocal Teaching Method, the result of this study is able to enhance the students to understand what had been read. In addition, reciprocal teaching could make students more active and motivated in joining reading class, be brave to give and share their idea, improve leadership, increase co-operation and have greater initiative in doing the task.

\section{CONCLUSION (Font size: 12 Bold in Capital Letters, Times New Roman)}

Reciprocal Teaching Method is one of the teaching methods that can be employed to teach students in large classes by activating learners as subject of learning. To optimize the method, we can apply predicting, questioning, clarifying, and summarizing. After implementing Reciprocal Teaching Method, the researcher concludes the following important points:

1. They could overcome their problems in understanding text dealing with finding main idea, finding word reference, finding explicit information, and finding meaning of certain word successfully. Their scores are satisfactory for those three indicators. However, the students' problems deal with identifying implicit information could not successfully accomplish, since their mean scores were still under the passing grade. Overall the mean of the pre-test and the post-test scores are improving. The results show that there is a significant difference in reading scores achieved in the reading tasks before and after the implementation of reciprocal teaching method on the students' reading comprehension. It shows that teaching reading using reciprocal teaching method provided high contribution to improve the students' reading comprehension.

2. The students' learning motivation also indicates good improvement. They try to ask the teacher or their friend when they didn't understand the text. They must make conversation to do the task given from the teacher. Second, the students' effort towards the lesson is increasing. They become active and cooperative during the lectures and discussion. When the teacher asks questions, they try to answer it directly. Third, the students' persistence or self responsibility is also increasing. They read and make a dialog in the group discussion to discuss the texts and its task using reciprocal teaching method 
without waiting for the teacher's instruction. Fourth, students' optimal experience was increasing too. They felt that the teacher tried to use appropriate method. So, they are active in reading activity. There are no more passive students. They must involve in the learning activity. They have to ask and answer the question. Finally, they don't wait for the clever students who has finished the tasks and copied the answers again but they could finish the tasks by themselves. All students are participated actively in the teaching learning process. As a result, the teacher always gives reinforcement to the students because of their active participation in the discussion and in the finishing the tasks.

\section{REFERENCES}

Ahmadi, M. R. (2013). Goals of Reciprocal Teaching Strategy Instruction. The International Journal of Language Learning and Applied Linguistics World (IJLLALW), 2(1)(January 2013), 18-27.

Aini, A. N. (2011). Improving Students' Reading Comprehension Using Reciprocal Teaching (A classroom Action Research at the Eight Grade of SMPN 13 Surakarta in The Academic Year of 2010/2011. Sebelas Maret University of Surakarta.

McNif, J. (1992). Action Research: Principle And Practice. London: Macmillan Education, Witshire.

Palincsar. (1986). Strategies for Reading Comprehension Reciprocal. Retrieved April 11, 2012, from www.readingquest.org/strat/rt.html

Striklin, K. (2011). Hands-On Reciprocal Teaching: A Comprehension Technique. Retrieved January 11, 2013, from www.elsevier.com /locate/compedu

Sutri, D. (2009). Using Reciprocal Teaching Strategy to Improve The Reading Ability of The Second Year Students of MTSN Model KUOK in Comprehending Narrative Text. Riau University. 